\title{
STATUS AND DISTRIBUTION OF DIFFERENT POTASSIUM FORMS IN CALCAREOUS SOILS IN NORTHERN IRAQ
}

\author{
Waheeda. A-Badrani Radhwan. R ALI
}

Department of Soil Sciences and Water Resources, College of Agriculture and

Forestry, Mosul University, Iraq

Email:drwaheeda57@gmail.com

\begin{abstract}
1n the last few years, the demand increased especially in the developing countries for food production. One of the parameters to increase the production quantitatively and qualitatively is the use of fertilizers by following the modern techniques in fertilization which needs a detail soil studies. This study highlighted on behavior of different forms of potassium, their distributions through soil profile, and the relationships between them and with soil other properties.

To represent a detailed study of the potassium behavior, twenty two surface $(0-15 \mathrm{~cm})$ and subsurface $(15-30 \mathrm{~cm})$ soil samples were selected from Nineveh province. The soil chemical and physical properties of each location are different.

Distribution of different forms of $\mathrm{K}$ in these soils, i.e., available, water soluble $\left(\mathrm{H}_{2} \mathrm{O}-\mathrm{K}\right)$, exchangeable (NH4OAc-K), non-exchangeable (HNO3-K), mineral and Total forms were ranged from $(0.708$ to 1.167$),(0.006$ to 0.146$),(0.691$ to 1.124$),(1.150$ to 3.261$)$, (35.48 to 52.81$)$ and (38.78 to 58.65) respectively, for surface soil and $(0.559-0.997),(0.003-0.105),(0.554$ to 0.914$),(0.997$ to 2.801$)$, (30.04 to 56.77) and (32.55 to 60.88) respectively, for sub-surface soil. Correlation study showed that the various forms of $\mathrm{K}$ were positively and significantly correlated amongst themselves and with $\mathrm{CaCO}_{3}$ content of the soils negatively.

The water soluble, exchangeable; available; nonexchangeable and mineral potassium constituted only $0.075 ; 1.65 ; .1 .73 ; 3.95$ and 92.03 percent of the total$\mathrm{K}$ respectively.
\end{abstract}

Keywords:- calcareous soils, potassium, forms, exchangeable, non-exchangeable. Received: 10/4/2019 Accepted: 10/10/2019

\section{INTRODUCION}

Potassium is the major nutrient and also a most abundant element in soils but $\mathrm{K}$ content of the soil varies from place to place based on physicochemical properties of soil (Lalitha and Dhakshinamoorthy, 2014). It is one of the vital elements required for plant growth and physiology. It's classified as a macronutrient because plants up take large quantities during their life cycle. Most of the soils have large amounts of total-K but relatively small amount of available-K.

Potassium has an important role in plant growth and development such as activation of number of enzymes (around 70), involved in photosynthesis, metabolism of carbohydrates and protein, assists in synthesis and transportation of water, nutrients and carbohydrates, protein synthesis, membrane permeability, stoma regulation and water utilization. Improve utilization of $\mathrm{N}$, sunlight dry, cool and cloudy periods enhances plants to resist and overcame a biotic stresses created 
by drought, frost, salinity and disease (Rehm and Schmitt, 2002; Lakudzala 2013; Hasanuzzaman et al., 2018) Therefore, among the essential plant nutrients, potassium assumes greater significance since it is required in relatively larger quantities by plants and besides increasing the yield, it immensely improves the quality of the crop product.

Potassium in soil can be allocated to four forms, Water soluble- $\mathrm{K}$, which is taken up directly by plant, Exchangeable potassium, which is held by the negative charges on exchange site of clay and organic matter and is available to plant, Soil soluble and exchangeable potassium are in equilibrium and collectively known as the readily available potassium. fixed- $K$ which is trapped between layers of expanding lattice clays, and lattice $\mathrm{K}$ and integral part of primary $\mathrm{K}$ bearing minerals. Plants utilize not only the readily available- $\mathrm{K}$ but also the less readily available-K during their growth (Darunsontaya et al., 2012).

Although most of the Iraqi soils have been too reported to be rich in potassium but due to cultivation of high yields varieties of crops with optimum applications of high rates of $\mathrm{N}$ and $\mathrm{P}$ tend to deplete the $\mathrm{K}$ reserve of soil at faster rate. To formulate a good fertilizers recommendation, potassium supplying capacity of soil is essential. This will be depend not only on the available-K content of soil, but a sound knowledge of different forms of $\mathrm{K}$ and their relationship among themselves is also required. Therefore, the present investigation was carried out with the following objectives. To determine the distribution of potassium in surface and sub-surface soils of Agriculture in different forms and find the relationship of different forms of potassium with other important physic -chemical properties.

\section{MATERIALS AND METHODS}

To evaluate the depth distribution of $\mathrm{K}$ in soil profile sample were collected from two depths $(0-15$ and $15-30 \mathrm{~cm})$ at eleven location giving a total of 22 samples. These soil samples were air dried, crushed in wooden mortal and passed through $2 \mathrm{~mm}$ plastic sieve for physic-chemical analysis including texture, $\mathrm{pH}, \mathrm{EC}$, $\mathrm{OM}, \mathrm{CaCO}_{3}$ and $\mathrm{CEC}$, using the following standard procedures (Table 2).

Particle analysis, was carried out using the hydrometer method of Bouyoucos as described by Gee and Bauder, (1986). Different sizes that is sand, silt and clay was this determined by hydrometer. All the collected samples were analyzed (percent silt and clay was estimated by hydrometer and percent sand was calculated by subtracting silt and clay from 100). The $\mathrm{pH}$ values was determined in 1:1 soil water suspension after stirring for 30 minutes using a pH meter and EC meter(Page, 1982). was measured in 1:1 soil water suspension after stirring for 30 minutes using E.C meter (Page, 1982). Organic carbon was determined by wet oxidation method Walkelly and Black's as described by (Piper,1996). Cation exchange capacity (CEC) was determined using ammonium acetate method (Page, 1982).

Water soluble-K was estimated by shaking $1 \mathrm{~g}$ of soil with $1: 1$, soil, water ratio, after shaking for 30 minutes on mechanical shaker and later filtered to obtain clear extract according to Pratt, (1982). Exchangeable-K was determined by shaking $10 \mathrm{~g}$ of soil sample in $1 \mathrm{M}$ of NH4OAC (buffered at $\mathrm{pH} 7$ ) followed by filtration as describe by (Pratt, 1982). Non-exchangeable-K was determined using 5.0g of soil 
sample boiled in $50 \mathrm{~mL}$ of $1 \mathrm{M}$ HNO3 solution. The difference between $\mathrm{K}$ extracted through HNO3 and exchangeable- $\mathrm{K}$ was taken as non-exchangeable- $\mathrm{K}$ as describe by (Hay lock, 1956). Total-K was measured by digesting $2 \mathrm{~g}$ of soil samples with 20 $\mathrm{mL}$ of $\mathrm{HClO}-\mathrm{HNO} 3$ acid mixture and leached with $\mathrm{HCl}$ according to (Jackson,1958). Mineral-K was calculated by subtracting total-K from HN03 extractable. All K forms extract were analyzed using the flame photometer.

Table (1): Location of soil sampling site through GPS and classification of investigated studied soils.

\begin{tabular}{|c|c|c|c|c|}
\hline No & Location & N ( Latitude) & E ( Longitude) & Land Use \\
\hline 1 & Tel-Kafe & $36^{\circ} 28^{\prime} 41.34^{\prime \prime} \mathrm{N}$ & $43^{\circ} 07^{\prime} 51.55^{\prime \prime} \mathrm{E}$ & Vegetables \\
\hline 2 & Nazar Sead Mohammed & $36^{\circ} 32^{\prime} 27.63^{\prime \prime} \mathrm{N}$ & $43^{\circ} 03^{\prime} 53.66^{\prime \prime} \mathrm{E}$ & Cereal Crops \\
\hline 3 & Wana & $36^{\circ} 32^{\prime} 52.72^{\prime \prime} \mathrm{N}$ & $42^{\circ} 46^{\prime} 23.33^{\prime \prime} \mathrm{E}$ & Vegetables \\
\hline 4 & Kaber Al-Abid & $36^{\circ} 10^{\prime} 40.21^{\prime \prime} \mathrm{N}$ & $43^{\circ} 14^{\prime} 39.14^{\prime \prime} \mathrm{E}$ & Vegetables \\
\hline 5 & Qiara & $35^{\circ} 52^{\prime} 19.09^{\prime \prime} \mathrm{N}$ & $43^{\circ} 19^{\prime} 23.16^{\prime \prime} \mathrm{E}$ & Cereal Crops \\
\hline 6 & Shrikhan & $36^{\circ} 24^{\prime} 13.1^{\prime \prime} \mathrm{N}$ & $4^{\circ} 03^{\circ} 50.39^{\prime \prime} \mathrm{E}$ & Vegetable \\
\hline 7 & Ninevah Forest & $36^{\circ} 21^{\prime} 59.23^{\prime \prime} \mathrm{N}$ & $43^{\circ} 07^{\prime} 34.55^{\prime \prime} \mathrm{E}$ & Forests \\
\hline 8 & Bartilla &, $36^{\circ} 20^{\prime} 40.21 " \mathrm{~N}$ & $43^{\circ} 22^{\prime} 09.83^{\prime \prime} \mathrm{E}$ & Cereal Crops \\
\hline 9 & Al-Hamdanya & $36^{\circ} 19^{\prime} 14.66^{\prime \prime} \mathrm{N}$ & $43^{\circ} 24^{\prime} 54.42^{\prime \prime} \mathrm{E}$ & Cereal Crops \\
\hline 10 & Zamar & $36^{\circ} 25^{\prime} 98.16^{\prime \prime} \mathrm{N}$ & ${ }^{\circ} 43^{\circ} 42^{\prime} 04.23 " \mathrm{E}$ & Cereal Crops \\
\hline 11 & Al-Bastana Station & $36^{\circ} 19^{\prime} 48.5^{\prime \prime} \mathrm{N}$ & $4^{\circ} 43^{\circ} 10^{\prime} 10.9^{\prime \prime} \mathrm{E}$ & Vegetable \\
\hline
\end{tabular}

\section{1- Available potassium}

\section{RESULTS AND DISCUSSION}

The available-K content in the studied soils were ranged from $0.708-1.167$ cmol. $\mathrm{kg}^{-1}$ with a mean of $0.853 \mathrm{cmol} . \mathrm{kg}^{-1}$ for surface soil and $0.559-0.997 \mathrm{cmol} . \mathrm{kg}^{-}$ ${ }^{1}$ with a mean of $0.730 \mathrm{cmol}^{-\mathrm{kg}^{-1}}$ for subsurface soil (Table 3). The values of available-K were higher in the surface soils as well as sub surface depths. Similar results were also reported by (Mandal et al., 2011); (Siddiqua et al., 2018).

Table 4 presents the correlation analyses of different forms of $\mathrm{K}$ with soil properties which showed that available potassium was significantly and positively correlated with CEC $\left(\mathrm{r}=0.842^{* *}\right)$ clay $\left(\mathrm{r}=0.752^{* *}\right)$ and silt $\left(\mathrm{r}=0.610^{* *}\right)$ and negatively correlated with $\mathrm{CaCO}_{3}(\mathrm{r}=-0.780 * *)$.

Amongst $\mathrm{K}$ forms and available- $\mathrm{K}$ was significantly correlated with water soluble$\mathrm{K} \quad\left(\mathrm{r}=0.684^{* *}\right)$, exchangeable- $\mathrm{K}\left(\mathrm{r}=0.978^{* *}\right)$, non-exchangeable- $\mathrm{K}\left(\mathrm{r}=0.532^{* *}\right)$, total-K $\left(\mathrm{r}=0.623^{* *}\right)$ and lattice $\mathrm{K}\left(\mathrm{r}=0.546^{* *}\right)$. Similar results were also reported by (Saini and Grewal.,2014). The positive correlations between forms of potassium with other forms indicates that the available-K is governed by the other forms of potassium in the soil. 
Mesopotamia J. of Agric.

Vol. (47) No. (2) 2019
ISSN: 2224 - 9796 (Online)

ISSN: 1815 - $316 \mathrm{X}$ (Print)
مجلـــــة زر اعـــة الــر افديـن

المجلد (47) العدد (2) 2019

Table (2): Selected physical and chemical properties in the soil studied

\begin{tabular}{|c|c|c|c|c|c|c|c|c|c|c|}
\hline \multirow{2}{*}{$\begin{array}{c}\text { Soil } \\
\text { No }\end{array}$} & Depth & EC & PH & $\begin{array}{l}\text { Cmol } \\
\text { Kg-1 }\end{array}$ & \multicolumn{5}{|c|}{ gm . Kg } & \multirow{2}{*}{ Texture } \\
\cline { 2 - 12 } & Cm & ds.m-1 & & CEC & O.M & CaCO $_{3}$ & Sand & Silt & Clay & \\
\hline \multirow{2}{*}{1} & $0-15$ & 2.62 & 7.2 & 23.3 & 9.77 & 379.8 & 253 & 355 & 392 & Clay loam \\
\cline { 2 - 12 } & $15-30$ & 0.21 & 7.22 & 24.4 & 8.08 & 387.9 & 378 & 130 & 492 & Clay \\
\hline \multirow{2}{*}{2} & $0-15$ & 1.12 & 7.13 & 23 & 8.25 & 302.2 & 190.5 & 330 & 479.5 & Clay \\
\cline { 2 - 12 } & $15-30$ & 0.11 & 7.2 & 26 & 6.185 & 342.1 & 190.5 & 292.5 & 517 & Clay \\
\hline \multirow{3}{*}{3} & $0-15$ & 1.54 & 7.3 & 23.1 & 8.595 & 271.1 & 250.5 & 392.5 & 357 & Clay loam \\
\cline { 2 - 12 } & $15-30$ & 1.1 & 7.11 & 25 & 6.185 & 299 & 450.5 & 175 & 374.5 & Sandy clay \\
\hline \multirow{3}{*}{4} & $0-15$ & 0.5 & 7.21 & 24 & 19.25 & 281.1 & 379.2 & 357.5 & 263.3 & Loam \\
\cline { 2 - 12 } & $15-30$ & 1.5 & 7.18 & 26.5 & 8.075 & 301.1 & 442.5 & 267.5 & 290 & Clay loam \\
\hline \multirow{2}{*}{5} & $0-15$ & 0.31 & 7.8 & 20.1 & 15.6 & 254.9 & 379 & 321 & 300 & Clay loam \\
\cline { 2 - 12 } & $15-30$ & 0.3 & 7.53 & 24.7 & 11.5 & 295 & 240.5 & 405 & 354.5 & Clay loam \\
\hline \multirow{2}{*}{6} & $0-15$ & 3.1 & 7.4 & 20 & 21.8 & 279.3 & 312.5 & 417.5 & 270 & Clay loam \\
\cline { 2 - 12 } & $15-30$ & 3.13 & 7.6 & 20 & 16.56 & 306.2 & 317.5 & 382.5 & 300 & Clay loam \\
\hline \multirow{2}{*}{7} & $0-15$ & 2.34 & 7.8 & 19 & 39.75 & 230.9 & 459 & 406 & 135 & Loam \\
\cline { 2 - 12 } & $15-30$ & 1.61 & 7.6 & 22 & 18.7 & 281.7 & 518 & 354.4 & 127.6 & Loam \\
\hline \multirow{2}{*}{8} & $0-15$ & 0.22 & 7.8 & 20.8 & 20.6 & 228.7 & 448 & 335 & 217 & Loam \\
\cline { 2 - 12 } & $15-30$ & 0.2 & 7.58 & 20.2 & 13.2 & 258.7 & 390.5 & 300 & 309.5 & Clay loam \\
\hline \multirow{2}{*}{9} & $0-15$ & 0.23 & 7.53 & 22 & 19.2 & 281.7 & 340.5 & 267.5 & 392 & Clay loam \\
\cline { 2 - 11 } & $15-30$ & 0.31 & 7.11 & 23 & 17.15 & 310 & 310 & 370 & 320 & Clay loam \\
\hline \multirow{2}{*}{10} & $0-15$ & 0.22 & 7.15 & 24 & 8.075 & 281.7 & 352.9 & 311.3 & 335.8 & Clay loam \\
\cline { 2 - 10 } & $15-30$ & 0.12 & 7.33 & 23 & 10.95 & 335.4 & 278 & 305 & 417 & Clay \\
\hline \multirow{2}{*}{11} & $0-15$ & 4.53 & 7.53 & 20 & 14.9 & 259.8 & 408 & 362.5 & 229.5 & Loam \\
\cline { 2 - 10 } & $15-30$ & 4.4 & 7.11 & 25 & 11.5 & 327 & 399.5 & 331.2 & 269.3 & Loam \\
\hline
\end{tabular}


Mesopotamia J. of Agric.

Vol. (47) No. (2) 2019
ISSN: 2224 - 9796 (Online)

ISSN: 1815 - $316 \mathrm{X}$ (Print)

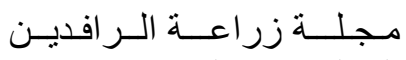

المجلد (47) العدد (2) 2019

Table (3): Potassium forms in the studied soil of north of Iraq $\left(\mathrm{Cmol} . \mathrm{kg}^{-1}\right)$

\begin{tabular}{|c|c|c|c|c|c|c|c|c|}
\hline \multirow{2}{*}{$\begin{array}{c}\text { S } \\
\text { No }\end{array}$} & Depth & \multicolumn{7}{|c|}{ Cmol.Kg-1 } \\
\hline & $\mathrm{Cm}$ & Soluble & $\begin{array}{c}\text { Exchange } \\
\text { Able }\end{array}$ & Available & Step & $\mathrm{Kn}$ & Min & Total \\
\hline \multirow{2}{*}{1} & $0-15$ & 0.013 & 0.694 & 0.708 & 1.765 & 0.725 & 35.486 & 38.783 \\
\hline & $15-30$ & 0.004 & 0.554 & 0.559 & 1.1 & 0.556 & 38.516 & 40.7 \\
\hline \multirow{2}{*}{2} & $0-15$ & 0.006 & 0.751 & 0.758 & 1.228 & 0.883 & 40.603 & 43.488 \\
\hline & $15-30$ & 0.003 & 0.595 & 0.598 & 1.253 & 0.625 & 30.042 & 32.55 \\
\hline \multirow{2}{*}{3} & $0-15$ & 0.022 & 0.795 & 0.818 & 1.176 & 0.93 & 47.663 & 50.632 \\
\hline & $15-30$ & 0.009 & 0.649 & 0.658 & 1.151 & 0.66 & 42.516 & 45 \\
\hline \multirow{2}{*}{4} & $0-15$ & 0.027 & 0.691 & 0.718 & 2.353 & 0.795 & 39.972 & 44 \\
\hline & $15-30$ & 0.011 & 0.607 & 0.618 & 2.788 & 0.608 & 41.994 & 46 \\
\hline \multirow{2}{*}{5} & $0-15$ & 0.032 & 0.985 & 1.017 & 2.839 & 1.49 & 45.564 & 51.071 \\
\hline & $15-30$ & 0.018 & 0.859 & 0.878 & 2.801 & 1.35 & 43.589 & 48.618 \\
\hline \multirow{2}{*}{6} & $0-15$ & 0.069 & 0.938 & 1.007 & 3.261 & 1.35 & 52.811 & 58.654 \\
\hline & $15-30$ & 0.063 & 0.914 & 0.977 & 2.174 & 1.075 & 54.574 & 59 \\
\hline \multirow{2}{*}{7} & $0-15$ & 0.146 & 1.016 & 1.167 & 2.609 & 1.655 & 41.297 & 46.798 \\
\hline & $15-30$ & 0.105 & 0.892 & 0.997 & 1.841 & 1.156 & 56.77 & 60.884 \\
\hline \multirow{2}{*}{8} & $0-15$ & 0.032 & 1.124 & 1.157 & 2.481 & 1.513 & 47.562 & 53 \\
\hline & $15-30$ & 0.011 & 0.896 & 0.908 & 1.714 & 0.975 & 48.367 & 51.963 \\
\hline \multirow{2}{*}{9} & $0-15$ & 0.012 & 0.785 & 0.798 & 2.251 & 1.075 & 51.257 & 55.431 \\
\hline & $15-30$ & 0.005 & 0.753 & 0.758 & 2.123 & 1.15 & 47.286 & 51.517 \\
\hline \multirow{2}{*}{10} & $0-15$ & 0.008 & 0.749 & 0.754 & 1.151 & 0.75 & 48.613 & 51.268 \\
\hline & $15-30$ & 0.004 & 0.634 & 0.638 & 0.997 & 0.674 & 36.142 & 38.451 \\
\hline \multirow{2}{*}{11} & $0-15$ & 0.118 & 0.859 & 0.977 & 1.304 & 1.213 & 39.263 & 42.819 \\
\hline & $15-30$ & 0.081 & 0.686 & 0.768 & 1.228 & 0.986 & 38.436 & 41.481 \\
\hline
\end{tabular}

\section{2- Water soluble potassium}

The water soluble $\mathrm{H}_{2} \mathrm{O}-\mathrm{K}$ in calcareous soils of Northern Iraq varied from 0.006-0.146 Cmol. $\mathrm{Kg}^{-1}$ with a mean of $0.044 \mathrm{Cmol}^{-\mathrm{Kg}^{-1}}$ for surface soil. The subsurface water soluble-K content varied from $0.003-0.105 \mathrm{cmol}^{\mathrm{kg}} \mathrm{kg}^{-1}$ with a mean of $0.028 \mathrm{cmol} . \mathrm{kg}^{-1}$ table 3. Similar results were also reported by (Siddiqua et al., 2018.)

Maximum values of surface and subsurface soil water soluble-K was 0.146 cmol. $\mathrm{kg}^{-1}$ and $\mathrm{K} 0.105 \mathrm{cmol}^{\mathrm{kg}}{ }^{-1}$ observed in location 7 . While, the minimum value of water soluble $\mathrm{K}$ in surface soil $0.006 \mathrm{cmol} . \mathrm{kg}^{-1}$ and sub-surface $0.003 \mathrm{cmol} . \mathrm{kg}^{-1}$ was noticed in location 2 respectively. 
In general, most of the soils recorded higher water soluble-K at surface as well as sub-surface. This variation might be due to nature and intensities of cropping pattern, clay content, weathering stages of $\mathrm{K}$ bearing minerals (primary and secondary) and organic matter content in soil. Similar results were reported by (Subba Rao et al., 1991); (Raskar and Pharande., 1997).

The data in table 3 showed that the level of soluble potassium is too small comparing with other potassium forms. It is also evident that soluble potassium comprises no more than 0.060 and 0.090 percent of total potassium in the soil two successive layers. These results is in agreement with (Ghiri1 and Abtahi., 2011). the study showed that soluble-K comprised only 0.03 and 0.06 percent of the total-K in the surface and subsurface soils respectively.

The values of the correlation coefficients for different soil properties and soil $\mathrm{K}$ forms in selected locations are presented in table 4 . Water soluble-K was highly and significantly correlated at $1 \%$ probability level with exchangeable potassium $(\mathrm{r}=0.520 * *)$, available potassium $\left(\mathrm{r}=0.684^{* *}\right)$ and $\mathrm{Kn}$ potassium $(\mathrm{r}=0.607 * *)$. These results agreed with (Samadi et al., 2010) which found a positive correlation between water soluble with exchangeable $\left(\mathrm{r}=0.946^{* *}\right)$, and available-K $(\mathrm{r}=0.967 * *)$ at $\mathrm{P}<0.05$. This observation was not unexpected because exchangeable potassium is usually released into the soil solution from the exchange complex when plants deplete the soluble potassium which indicate that the exchangeable potassium pool will determine the effectiveness of $\mathrm{K}$ re-supply, as well as the concentration of $\mathrm{K}$ in the soil solution.

The positive correlation coefficients between this form of $\mathrm{K}$ with other forms indicates that the available-K was governed by the other forms like total and nonexchangeable potassium. Water soluble-K was also found that significantly and positively correlated with the soil properties such as CEC $\left(\mathrm{r}=0.566^{* *}\right)$, clay $\left(\mathrm{r}=0.775^{* *}\right)$, silt $\left(\mathrm{r}=0.477^{*}\right)$, EC $\left(\mathrm{r}=0.707^{* *}\right)$ and O.M $\left(\mathrm{r}=0.695^{* *}\right)$. The water soluble-K showed a positive correlation with sand $\left(\mathrm{r}=0.504^{* *}\right)$, which may be due to the fact that $\mathrm{K}$ ion present on sand particles can release easily into the solution (Al-Zubaidi and Pagel, 1979).

\section{3- Exchangeable potassium}

Exchangeable potassium $\left(\mathrm{NH}_{4} \mathrm{OAc}-\mathrm{K}\right)$, which was held by the exchange sites of negative charges on soil clay and organic matter, plays a very important role in the growth of plants. Exchangeable and solution potassium ware only sources of potassium which are readily available to plants. The exchangeable potassium ware in equilibrium and collectively known as the readily available potassium pool (Shaikh et al., 2007).

The exchangeable potassium content of calcareous soils of Northern of Iraq varied from (0.691 to 1.124) $\mathrm{Cmol}_{\mathrm{Kg}}{ }^{-1}$ in surface layer. The sub-surface exchangeable-K content varied from (0.554 to 0.914) $\mathrm{Cmol.} \mathrm{Kg}^{-1}$. The mean value of exchangeable-K was (0.853 and 0.730$) \mathrm{mg} \mathrm{kg-1}$ in surface and sub-surface layers, respectively.

The calcareous soils recorded more exchangeable potassium at surface as well as sub surface depths.. The higher exchangeable-K status of surface layer could be due to application of $\mathrm{K}$ fertilizers, crop residue, high organic carbon content and 
higher biological activities. These findings were similar with the results observed by Raskar and Pharande, (1997) for black soils of Maharashtra.

The higher exchangeable-K status of surface layer could be due to the high degree of weathering of the surface soil, the release of soluble-K from crop residue , the addition of $\mathrm{K}$ fertilizers, high organic carbon content, higher biological activities and the upward translocation of soluble-K due to the capillary rise of the groundwater (Venkatesh and Satyanarayana., 1994). These findings were similar with the results observed by (Saini and Grewal.,2014).

Exchangeable-K was highly and significantly correlated at $1 \%$ level of probability with available-K $\left(\mathrm{r}=0.978^{* *}\right)$, water soluble-K $\left(\mathrm{r}=0.520^{* *}\right)$, step ( $\mathrm{r}=$ $\left.0.560^{* *}\right), \mathrm{Kn}(\mathrm{r}=0.914 * *)$, nonexchangeable-K $\left(\mathrm{r}=0.560^{*}\right)$, total-K $(\mathrm{r}=0.659 * *)$ and lattice $\mathrm{K}\left(\mathrm{r}=0.583^{* *}\right)$. These findings are similar to those of Singh et al., (2001) and Gangopadhyay et al., (2005). The correlation of this form of $\mathrm{K}$ with others indicated that the different forms of $\mathrm{K}$ are in dynamic equilibrium.

The values of correlation coefficient of exchangeable-K with soil properties showed that non exchangeable-K was significantly and positively correlated with CEC ( $\mathrm{r}=0.827 * *)$ which may due be due to fact that increases in CEC, which in turn might have increased exchangeable $\mathrm{K}$, organic carbon $\left(\mathrm{r}=0.676^{* *}\right)$, and clay content $\left(\mathrm{r}=0.664^{* *}\right)$, while whereas negatively correlated with $\mathrm{CaCO} 3\left(\mathrm{r}=-0.791^{*}\right)$. These results are in agreement with the findings of Mishra and Srivastava, (1993), (Das et al., 2000), (Singh et al., 2001) and (Sharma et al., 2009).

\section{4- Non- exchangeable potassium}

Nonexchangeable or fixed $\mathrm{K}$ differs from mineral-K that becomes slowly available to plants over the growing season in that it was not bonded within the crystal structures of soil mineral particles. It is held between adjacent tetrahedra layers of di octahedral and tri-octahedral mica, vermiculites, and intergrade clay minerals such as vermiculite (Sparks and Huang, 1985; Sparks, 1987).

Nitric acid soluble-K $\left(\mathrm{HNO}_{3}-\mathrm{K}\right)$ is most frequently used as a measure of nonexchangeable-K which constitutes major part of the total-K. Acid (HNO3) extractable potassium, which is used as an index of non-exchangeable potassium and represents the supplying power of potassium for long-term cropping (Jackson., 1958) are shown in Table 3.

It was observed that the non-exchangeable-K varied from 1.150 to 3.261 $\mathrm{Cmol} . \mathrm{Kg}^{-1}$ in surface layer. The sub-surface Non-exchangeable-K content varied from 0.997 to $2.801 \mathrm{Cmol} . \mathrm{Kg}^{-1}$. The average non-exchangeable potassium in surface soils of calcareous soils recorded (2.038) $\mathrm{Cmol}_{\mathrm{Kg}}{ }^{-1}$ while sub-surface layer recorded $1.742 \mathrm{Cmol} . \mathrm{Kg}^{-1}$. In general there was no uniformity in the distribution of non-exchangeable-K within the profiles.

If we consider the critical value for non-exchangeable potassium to be 1.00 Cmol.Kg- ${ }^{1}$ (400) mg kg-1, as suggested by Pagel., (1972), then the values of nonexchangeable potassium in twenty one soil samples are above this level (high in supplying power), and the remainder of the soil samples can be described as poor in supplying potassium.

correlation study of non-exchangeable-K with soil properties showed that it was significantly and positively correlated with silt $\left(\mathrm{r}=0.443^{*}\right)$, organic carbon 
$\left(\mathrm{r}=0.578^{* *}\right)$ and clay content $(\mathrm{r}=0.479 *)$, while whereas negatively correlated with $\mathrm{CaCO} 3(\mathrm{r}=-0.414 *)$. (Sharma et al.,2009) also reported similar results with different soil. The nonexchangeable $\mathrm{K}$ was also positively and significantly correlated with exchangeable- $\mathrm{K}\left(\mathrm{r}=0.560^{* *}\right), \mathrm{Kn}\left(\mathrm{r}=0.633^{* *}\right)$ and total- $\mathrm{K}\left(\mathrm{r}=0.510^{* *}\right)$.

\section{5- Mineral-K}

The mineral-K fraction of the soils was considered as difficultly available to the plants. Plants cannot use the potassium in these forms. However, with time, these minerals eventually break down, and small quantities of potassium are released to the soil solution. It found in the feldspars, mica and clay minerals which are part of the soil. The content of this K-form depends on soil type, type of primary , secondary minerals, types and quantities of clay minerals, removal of $\mathrm{K}$ from , the degree of weathering on the particle-size distribution,and environmental conditions (Rich., 1968) ; (Sharpley., 1987); (Das et al., 1993) ;( Dhakad et al., 2017).

The mineral-K content of calcareous soils of Northern Iraq varied 35.48 to 52.81 Cmol. $\mathrm{Kg}^{-1}$ in surface layer. The sub-surface mineral-K content varied 30.04 to $56.77 \mathrm{Cmol} . \mathrm{Kg}^{-1}$. The mean values of the mineral- $\mathrm{K}$ in calcareous soils was ranged from 44.55 to $43.47 \mathrm{Cmol.} \mathrm{Kg}^{-1}$ in surface and sub-surface samples, respectively, Decreased non-exchangeable-K with soil depth has been reported (Ngwe et al., 2012). However, in case of sub-surface soil such contribution of mineral-K total-K was ranged from 91.44 to $92.65 \mathrm{Cmol} . \mathrm{Kg}^{-1}$, with a mean value of 92.03 percent Table 3.

A highly significant ( $1 \%$ level) and positive correlation was also found between lattice $\mathrm{K}$ and total-K $\left(\mathrm{r}=0.990^{* *}\right)$. These results have indicated the existence of dynamic equilibrium between forms of $\mathrm{K}$ in soils and depletion of one is instantly replenished by one or more of the other forms of $\mathrm{K}$. These results are in agreement with the findings of (Mandal et al., 2011) also observed the per cent contribution of mineral $\mathrm{K}$ to total $\mathrm{K}$ in soils was $>90 \%$, thus indicating the dominance of this form over the other forms of $\mathrm{K}$.

The correlation values for different soil $\mathrm{K}$ forms in selected soil types are presented in tables 4 . The mineral- $\mathrm{K}$ was highly and significantly correlated at $1 \%$ level of probability with exchangeable potassium $\left(\mathrm{r}=0.783^{*}\right)$, step potassium $(\mathrm{r}=$ $\left.0.410^{* *}\right)$, and $\mathrm{Kn}$ potassium $\left(\mathrm{r}=0.445^{*}\right)$.

The mineral-K was significantly and positively correlated with clay $(\mathrm{r}=0$. $0.490^{* *}$ ) which may be due to presence of $\mathrm{K}$ bearing minerals in clay content and silt fractions. Similar trend followed for total-K as that of mineral-K as much of mineral- $\mathrm{K}$ is contributed to total- $\mathrm{K}$ and finer fractions of soils rich in $\mathrm{K}$-bearing minerals as it is evident from the correlation coefficients. The mineral- $\mathrm{K}$ was significantly and positively correlated with CEC $(\mathrm{r}=0.491 * *)$, and $\mathrm{pH}\left(\mathrm{r}=0.423^{*}\right)$ whereas negatively correlated with $\mathrm{CaCO} 3\left(\mathrm{r}=-0.498^{* *}\right)$. The present results were in agreement with the findings of (Kundu et al., 2014), (Jagmohan and Grewal., 2014).

\section{6 - Total potassium}

Total-K was a large portion of the total potassium in soil occurs as structural component of soil minerals and was unavailable to plants (Lalitha and 
Mesopotamia J. of Agric.

Vol. (47) No. (2) 2019
ISSN: 2224 - 9796 (Online)

ISSN: 1815 - $316 \mathrm{X}$ (Print)

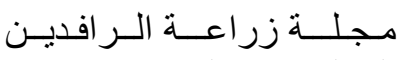

المجلد (47) العدد (2) 2019

Dhakshinamoorthy., 2014). The content of total potassium depends on the type of parent material, type of primary and secondary minerals and type of soil fractions.

The total potassium content of calcareous soils of Northern Iraq varied from 38.78 to $58.65 \mathrm{Cmol} . \mathrm{Kg}^{-1}$ in surface layer. The sub-surface total potassium in the studied soils content varied from 32.55 to $60.88 \mathrm{Cmol}_{\mathrm{Kg}}{ }^{-1}$. The average values of The total-K in was high in the studied calcareous soils 48.72 and $46.92 \mathrm{Cmol} . \mathrm{Kg}^{-1}$ in surface and sub-surface samples, respectively. The higher content in higher altitude may be attributed due to the presence of illite, mica and feldspars as a primary potassium bearing minerals which are capable of releasing large amount of potassium. Similar results were also reported by (Mushtaq and Raj, 2008 ).

More than $92.03 . \%$ of the total potassium in the studied soils was in the mineral phase, only $1-2 \%$ of the total soil potassium is in a readily available form plant Continuous crop production without potassium application may result in mica weathering to biotite, vermiculite or smectite and decomposition of feldspar structure over a longer period of time (Shaikh et al., 2007).

The water soluble, exchangeable; available ; nonexchangeable and mineral potassium constituted only $0.075 ; 1.65 ; .1 .73 ; 3.95$ and 92.03 percent of the total$\mathrm{K}$, indicating that the percent contribution of mineral- $\mathrm{K}$ to total- $\mathrm{K}$ in these soils was $>90$ percent. It can be inferred that dominance of this form of K over the other forms. Similar observation were made by (Sharma et al., 2009).

Table (4): Coefficients of correlation amongst different forms of potassium and some properties soil

\begin{tabular}{|c|c|c|c|c|c|c|c|}
\hline & $\begin{array}{c}\text { Water } \\
\text { soluble K }\end{array}$ & $\begin{array}{c}\text { Exchangeable } \\
\mathrm{K}\end{array}$ & $\begin{array}{c}\text { Available } \\
\text { K }\end{array}$ & Step K & $\mathrm{Kn}$ & $\begin{array}{c}\text { Mineral } \\
\mathrm{K}\end{array}$ & Total K \\
\hline Water soluble-K & 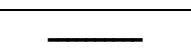 & & & & & & \\
\hline Exchangeable-K & $0.520 * *$ & 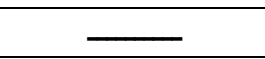 & & & & & \\
\hline Available-K & $0.684 * *$ & $0.978 * *$ & & & & & \\
\hline Step-K & 0.223 & $0.560 * *$ & $0.532 * *$ & - & & & \\
\hline $\mathrm{Kn}$ & $0.607 * *$ & $0.914 * *$ & $0.926 * *$ & $0.633 * *$ & & & \\
\hline Mineral-K & 0.212 & $0.583 * *$ & $0.546 * *$ & $0.410 *$ & $0.445^{*}$ & & \\
\hline Total-K & 0.266 & $0.659 * *$ & $0.623 * *$ & $0.510 * *$ & $0.542 * *$ & $0.990 * *$ & - \\
\hline CEC & $0.566^{* *}$ & $0.827^{* *}$ & $0.842 * *$ & 0.354 & $0.739 * *$ & $0.491 * *$ & $0.542^{* *}$ \\
\hline O.M & $0.695 * *$ & $0.676 * *$ & $0.747 * *$ & $0.578 * *$ & $0.763 * *$ & 0.324 & 0.41 \\
\hline Ec & $0.707 * *$ & 0.141 & 0.289 & & 0.2 & 0.011 & 0.03 \\
\hline $\mathrm{PH}$ & $0.503 * *$ & $0.857 * *$ & $0.853 * *$ & $0.515 * *$ & $0.795 * *$ & $0.423^{*}$ & $0.497 * *$ \\
\hline $\mathrm{CaCO} 3$ & $0.438 *_{-}$ & $0.791 * *_{-}$ & $0.780 * *_{-}$ & $0.441 *_{-}$ & $0.719 * *_{-}$ & $0.498 * *_{-}$ & $0.553 * *_{-}$ \\
\hline Clay & $0.775 * *$ & $0.664 * *$ & $0.752 * *$ & $0.479 *$ & $0.658 * *$ & $0.490^{*}$ & $0.547 * *$ \\
\hline Silt & 0.477 * & $0.580 * *$ & $0.610 * *$ & $0.443^{*}$ & $0.621 * *$ & 0.28 & 0.346 \\
\hline Sand & $0.504 * *$ & 0.297 & 0.374 & 0.195 & 0.259 & 0.336 & 0.348 \\
\hline
\end{tabular}

*and ** significant at $0.01,0.05$ probability level, respectively 
The total-K was significantly and positively correlated with clay content $\left(\mathrm{r}=0.547^{* *}\right), \mathrm{CEC}\left(\mathrm{r}=0.542^{* *}\right)$, and $\mathrm{pH}\left(\mathrm{r}=0.497^{* *}\right)$ Similar observation were made by (Sharma et al., 2006). These relationships explain that the finer fractions of the soils are in primary sources of potassium in the soils. The results also point out that the light textured soils would be depleted easily than heavy textured for native potassium. Therefore, continuous monitoring of soil potassium status is essential in these types of soils. whereas negatively correlated with $\mathrm{CaCO} 3\left(\mathrm{r}=-0.553^{* *}\right)$ and non-significantly and positively corrected with organic carbon ( $\mathrm{r}=0.410)$.

\section{CONCLUSION}

Potassium is very important for plant survival under all condition. It is not only a part of the chemical structure but also plays vital regulatory function in biochemical and physiological processes that contribute to plant growth and development .Results obtained in the present investigation thus, revealed that distribution of different $\mathrm{K}$ forms in soils is greatly influenced by soil properties and inter-relationships amongst themselves. Mineral-K contributed maximum than $(92$ $\%)$ towards total-K. The positive correlation with clay $\left(r=0.757^{*}\right)$ showed that some of $\mathrm{K}+$ adsorbed are on the edge of inner side of lattice, which could be replaced by exchangeable sites. Further highly significant and positive correlation was observed between different forms of $\mathrm{K}$, indicating the existence of equilibrium between these forms of $\mathrm{K}$ and depletion of one is instantly replenished by one or more of the other forms of $\mathrm{K}$. 
Mesopotamia J. of Agric.

Vol. (47) No. (2) 2019

ISSN: 2224 - 9796 (Online)

ISSN: 1815 - $316 \mathrm{X}$ (Print)

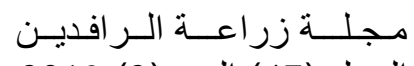

المجلد (47) العدد (2) 2019
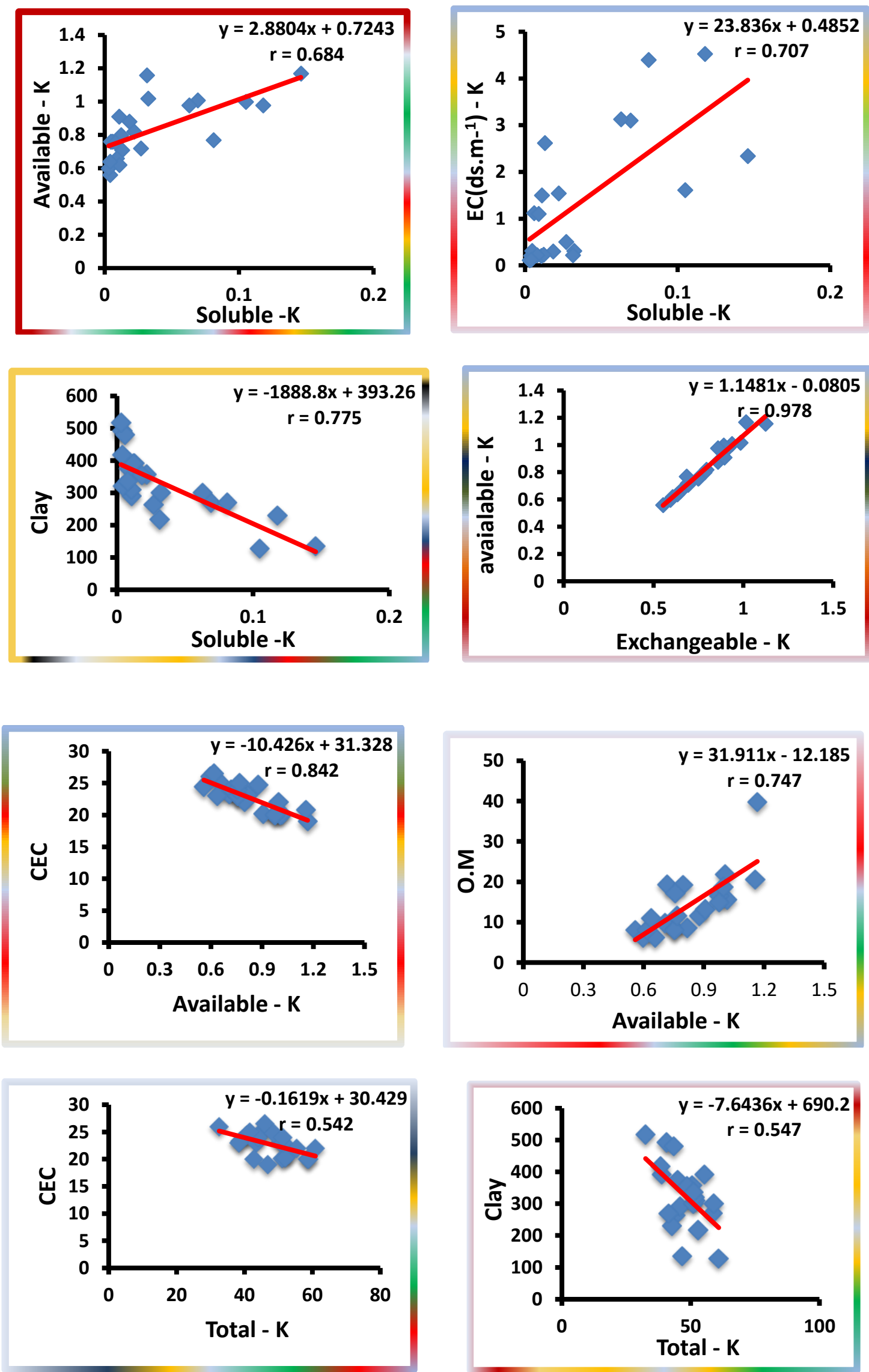

Fig (1) Inter- relationship between different forms of potassium, soil properties 


\section{حالة وتوزيع صور البوتاسيوم المختلفة في بعض الترب الكلسية شمال العراق

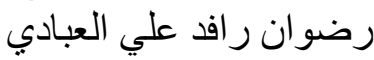 \\ قسم التربة و الموارد المائية ـ كلية الزر اعة و الغاباتـ جامعة الموصل رفل \\ Email:drwaheeda57@gmail.com}

\begin{tabular}{|c|}
\hline 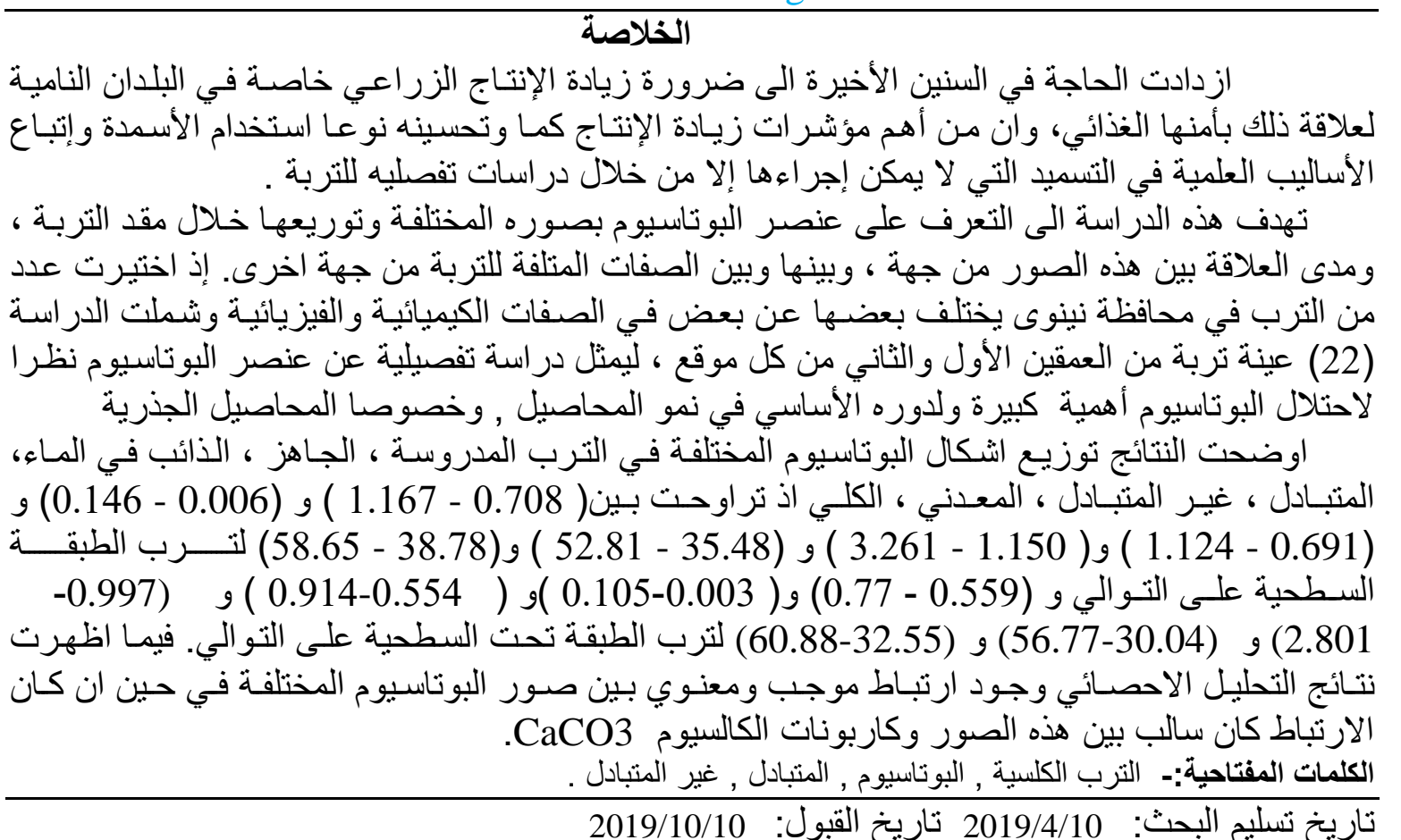 \\
\hline
\end{tabular}

\section{REFERENCES}

Al - Zubaidi, A. and H. Pagel. (1979). Content of different potassium forms in some Iraqi soils. Iraqi J. Agric. Sci XIV. 214-240.

Darunsontaya, T., A. Suddhaprikarn, I. Kheoruenromne, Prakongkep and Gilkes, R.J. (2012). The forms and availability to plants of soil potassium as related to mineralogy for upland Oxisols and Ultisols from Thailand. Geoderma, 170: 11-24.

Das, K. Sign S.K. and Shyampura R.L. (1993). Forms of K in relation to land form and soil properties of Basaltic terrian. J. Indian Soc. Soil Sci., 41: 557-559.

Dhakad, H., Yadav, S. S., Jamra, S., Arya, V., Sharma, K., \& Gaur, D. (2017). Status and Distribution of Different Forms of Potassium in Soils of Gwalior District (MP). IJCS, 5(5), 161-164.

Gangopadhyay, S.K., Sarkar D., Sahoo, A.K. and Das, K. 2005. Forms and distribution of potassium in some soils of Ranchi plateau. J. Indian Soc. Soil Sci., 53: 413-16.

Gee, G.W., and J.W. Bauder. (1986). Particle-Size Analysis. p. 383-411. In A. Klute (ed.) Methods of Soil Analysis. Part 1. 2nd ed. Agron. Monogr. 9. ASA and SSSA, Madison, WI.

Ghiri1 M, Abtahi A. (2011). Potassium dynamics in calcareous vertisols of southern Iran. Arid Land Research and Management, 25:257-274.

Hasanuzzaman. M 1,*, M. H. M. Borhannuddin Bhuyan 2,3 ID , Kamrun Nahar 4 , Md. Shahadat Hossain 2 , Jubayer Al Mahmud 5 , Md. Shahadat Hossen 1 , 
Abdul Awal Chowdhury Masud 1 ID , Moumita 1 and Masayuki Fujita 2, (2018)Potassium: A Vital Regulator of Plant Responses and Tolerance to Abiotic Stresses. www.mdpi.com/journal/agronomy.

Haylock , O.F. (1956) A method for estimating the availability of nonexchangeable potassium. 6th. Int . Cong . Soil Sci : P 403-408.

Jackson, M. L. (1958). Soil Chemical Analysis. Prentice - Hall Inc. Englewood cliffs., New Jeresy.

Jagmohan S, Grewal KS.(2014) Vertical distribution of different forms of potassium and their relationship with different soil properties in some Haryana soil under different crop rotation. Adv. Pl. Agric. Res. 1(2):1-52, 23-54.

Kundu, M. C., et al.(2014). Forms and distribution of potassium in some soils of Hooghly district of West Bengal. crucible 2.4: 4.

Lakudzala, D.D (2013). Potassium response in some Malawi soils. International Letters of Chemistry, Physics and Astronomy 8(2) 175-181.

Lalitha M, Dhakshinamoorthy M. (2014). Forms of Soil Potassium-A Review. Agricultural Reviews. 35(1): 64-68.

Mandal D, Dey SK, Baruah CB (2011). Forms of potassium and their distribution in rubber growing soils of Tripura. Ann. Pl. Soil Res. 13(2):75-79

Mushtaq, A.W. and Raj, K. 2008. Distribution of potassium and clay minerals assemblage in some paddy soils of Lesser Himalayas. Agropedology 18(2): 98-105.1

Ngwe, K., Kheoruenromne, I., \& Suddhiprakarn, A. (2012). Potassium status and physicochemical and mineralogical properties of lowland vertisols in a ricebased cropping system under tropical savanna climate. Kasetsart Journal (Natural Science), 46, 522-37.

Page, A. I., R. H. Miller, and D. R. Kenney (1982). Methods of Soil Analysis. Part 2. Agronomy 9, Madison, W.I.

Pagel, H. (1972). Vergleichende Untersuchungen Uber Gehalt An Austauschbarem And Nachlieferbaren kalium In Wichtigen Boden Der Ariden Und Humiden Tropen. Beit. Tropische und sub-trop

Piper, CS (1996). Soil and Plant Analysis. Inter Science Publishers. Inc. New York. Pratt. P.F. (1982). Potassium. In: Method of Soil Analysis. Part 2. C.F. page. et al., 1992.

Raskar, B.N., and Pharande, A.L. (1997). Different forms of potassium and their distribution in some important soil series of Vertisols and Alfisols of Western Maharashtra. J. Potassium Res., 13: 21-30.

Rehm, G., Schmitt, M. (2002). Potassium for Crop Production. Retrieved from The University of Minnesota Web site:

Rich, C. I. (1968). Mineralogy of soil potassium. In V. J. Kilmer, S.E. Younts and N.C. Brady (eds.), The role of potassium in agriculture. Am.

Saini JG, Grewal KS(2014). Vertical distribution of different forms of potassium and their relationship with different soil properties in some Haryana soil 
under different crop rotation. Department of soil science, CCS Haryana agricultural university; India. Plant and Agriculture Research, article. 1(2).

Samadi A., Rezapour S., Jafarzadeh A. A. and Oustan S. (2010). Impact of clay mineralogy and landscape on potassium forms in calcareous soils, Urmia Region. J. Agr. Sci. Tech. 12: 495-507.

Sharma, A., V. K Jalali, M. Vivak, Arya, and P. Rai. (2009). Distribution of various forms of potassium in soils representing intermediate zone of Jammu region. Journal of Indian Society of Soil Science 57(2): 205--207

Sharma, B.D., Mukhopadhyay S.S. and J.S. Sawhney. (2006). Distribution of potassium fractions in relation to landforms in a Himalayan catena. Archives of Agronomy and Soil Science. 52:469- 476.

Sharpley, A. N. (1987). The kinetics of soil potassium desorption. Soil Sci. Soc. Am. J. 51: $912-917$.

Sheikh, K., Memon, K. S., Memon, M., \& Akhtar, M. S. (2007). Changes in mineral composition and bioavailable potassium under long-term fertilizer use in cotton-wheat system. Soil Environ, 26(1), 1-9

Siddiqua, M., Sharma, S.H.K, Qureshi, A. and Laxminarayana, P., (2018) Assessment Of Potassium Supplying Capacity of Soils of Nalgonda District of Telangana State through Neubauer Seedling Technique, Int. J. Pure App. Biosci. 6(1): 551-555. doi: http://dx.doi.org/10.18782/23207051-5894.

Singh K., Malik R.V.S. and Sing V. (2001). Distribution of forms of potassium in alluvial soils. J. Potassium Res., 17: 116-18.

Sparks, D. L. (1987). Potassium dynamics in soils. In Advances in soil science (pp. 1-63). Springer, New York, NY.

Sparks, D.L. and P.G. Huang. (1985). The physical chemistry of soil potassium. In; R.E. Munson (ed.) Potassium in Agriculture. ASA, CSSA, Madison, W.I.

Subha Rao and Sekhon, G.S. (1991). Exchangeable potassium percentage as a measure of solution K in Vertisols and Vertic Ustocrepts. J. Indian Soc. Soil Sci., 39: 432-450.

Venkatesh, M. S., Satyanarayana, T. (1994): Status and distribution of potassium in Vertisols of North Karnataka. J. Indian Soc. Soil Sci., 42, 229-233. 